eight persons, and no doubt would be with a larger number. The hands should be moistened.

These experiments show in a simple and striking way that in the telephone we have an instrument which is sensitive to very minute electric impulses.

24, Southampton Buildings, W.C.

\section{ELIAS MAGNUS FRIES}

$\mathrm{B}^{\mathrm{Y}}$ the death of Fries, Sweden has lost one more of the line of eminent botanists whose labours have thrown a lustre so great upon Scandinavian science. Well versed in all domains of phanerogamic botany, and especially skilled in his native plants, it was amongst the cryptogams he spent the more active years of his long life. While lichenology owes to him valuable illustrations, fungology received at his hands a large element of its construction. In the acquisition, description, and systematic arrangement of the larger fungi he exhibited a zeal, a tact, and a perspicuity which seem to have left comparatively little to be done in later times, either by way of addition or improvement.

Elias Magnus Fries was born in Smalland on August I5, 1794. His father, pastor of the church at Femsjö, was an ardent and accomplished botanist. As there were no boys of his own age whom the young Fries could make companions, he constantly accompanied his father in his walks, and was in his earliest years made intimate with all the flowering plants of a district diversified by forest, mountain, marsh, and river. About the age of twelve he lighted upon an especially brilliant Hydnum, and was then first incited to the study of the Agarics and their allies, that abound in his native land more than in any other region of Europe. Before he left his school at Wexio he knew, and had given temporary names to, nearly 400 species. In 1 \& $r$ he eritered the University of Lund, where he had Schwartz, Agardh, and Rezius as his teachers; and in 1814 was chosen Docent of Botany. In this year he published his "Novitiæe Floræ Suecicæ," first part, the second part following in 1823 . In 1815 appeared his "Observationes Mycologicx," the first important result of his fungological researches. In the following year, dissatisfied with the method of Persoon, he began to construct an entirely new system. As a first fruit he wrote his "Specimen Systematis Mycologicæ," a tract of a few pages, and, in outline, his great work the "Systema Mycologicum," the first volume of which appeared in I 821 and the last in I829. In I 825 he sent forth the "Systema Orbis Vegetabilis," first part, a work not further completed, and in 1828 the "Elenchus Fungorum," a commentary on the Systema. In I $\delta_{3}$ I was published "Lichenographia Europea Reformata," and in 1838 his second great work, the "Epricisis Systematis Mycologici." About this time he completed the manuscript of a "Synopsis Ascomycetum," in which he had included upwards of 600 new species. Owing to his impatience of the critiques of Corda, Kunze, and the German fungologists who had begun to avail themselves of the new aid of the perfected microscope, an assistance which Fries denied himself, he refrained from publishing it, but one may hope this valuable MS. may still exist. In $\mathrm{I} 334$ he was made Professor of Practical Economy at Upsala, from which place he gave out the "Flora Scanica." He was sent to the Rigsdag in 1844 and 1848 as representative of his university, and was made a member of the Swedish Royal Academy in 1847 In 1851 he succeeded to the chair of Botany at Upsal, vacated by Wahlenberg, which he resigned only a few years before his death to his son. In 1846 he published the "Summa Vegetabilium Scandinaviæ", and in 1860 , "Sveriges ätliga och giftiga Svampar," with fine coloured plates. A project of the Royal Society of Holm to publish at its expense drawings of all species of Hymenomycetes under Fries's direction, induced him to write a third and fuller description of the Agarics, of which he printed oniy Ioo copies, under the title "of "Monographia Hymenomycetum Suecicæ," in $\mathrm{r} 863$. The first fasciculus, however, of the corresponding "Icones," appeared only in 1867 ; a second volume was commenced towards the end of last year. Fries lived at Upsal all the latter years of his life, in good health, and in constant correspondence with the botanists of this and other countries, taking, so far as his age permitted, all his early interest in his favourite Agarics. Thus he published, in 1874 , a second edition of his " Epicrisis," including in it all the later found Euro. pean species.

He died, after a short illness, on the Sth inst.

\section{THE TELEPHONE, AN INSTRUMENT OF PRECISION}

THE applications to which the telephone may in future be put cannot yet be all foreseen. I have to-day had its value shown to me in a remarkable way. $x$. I used a thermo-electric intermittent current by drawing a hot end of copper wire along a rasp completing the circuit. A telephone was put into the circuit, in another room, and every time that the wire was drawn along the rasp a hoarse croaking was heard in the telephone. 2. I used a thermopile with a Bunsen burner shining on it from a distance of six feet. The current was rendered intermittent by the file, and the sound was most distinctily heard. A Thomson's reflecting galvanometer was introduced into the circuit which showed that the currents were extremely small. 3. The feeblest attainable currents were now tried. The thermopile was removed, and without any artificial application of heat it was shown by the galvanometer that the natural differences in the temperatures of the different junctions in the circuit were sufficient to generate feehle electric currents only just pexceptible with the mirror galvanometer. These were easily detected by aid of the rasp and the telephone. Even when contact was simply made and broken with the hand, a click was heard in the telephone. 4. Lastly, these feeble currents were rendered still more insignificant by passing them through the body of a friend who held one end of the wire in each hand, and still the effects were faintly audible. Here the galvanometer, which was still in circuit, hardly gave any indication.

I have now added the telephone to the list of apparatus in the laboratory, considering it to be perhaps the most delicate test of an electric current which we possess.

In these experiments only one telephone is used, viz., at the receiving end. Employed in this way with a powerful current sent from the other end of the line, we may hope to have messages sent through submarine cables much more rapidly than at present. Probably it will be best to have the intermittent nature of the current maintained by an induction-coil, or by a spring rubbing against a continuously rotating $\operatorname{cog}$-wheel, when the current is allowed to pass only when required by the depression of a key which communicates to the listener at the receiving end the long and short dashes of the Morse alphabet.

I ought to mention that I believe the person who first used a thermo-electric current with a telephone was Prof. Tait.

Andersonian College, Glasgow, February I3

\section{OUR ASTRONOMICAL COLUMN}

LOHRMANN'S LUNAR CHARTS.-At last astronomers are put in possession of the charts of the moon's surface, commenced by W. G. Lohrmann, of Dresden, in 1821 . They are now completed in twenty-five sections; but previously only one part, containing four topographical sections, had been published. This was issued at Leipsic in 1824 ; a small general chart was lithographed at Dresden at a later period. It is through the active 